\title{
Double Negotiation: Iranian Women and the Global
}

\author{
Mohammad Rezaei ${ }^{1} \&$ Mona Kalantary ${ }^{2}$ \\ ${ }^{1}$ Department of Sociology, Tarbiat Modares University, Tehran, Iran \\ ${ }^{2}$ Department of Cultural Studies, University of Science and Culture, Tehran, Iran \\ Correspondence: Mona Kalantary, Department of Cultural Studies, University of Science and Culture, Tehran, \\ Iran. Tel: 98-91-2542-8188. E-mail: kalantary.mona@gmail.com
}

Received: April 21, 2016 Accepted: April 29, 2016 Online Published: June 21, 2016

doi:10.5539/ass.v12n7p236 URL: http://dx.doi.org/10.5539/ass.v12n7p236

\begin{abstract}
In this article we examine Iranian women's reading of Victoria, a very popular TV series in Iran. Based on Active Audience and especially Cross-Cultural Consumption Theory (CCCT), we tried to study how the audiences consume Victoria in different manners. By using a qualitative method, in depth interviewing among 30 women, and thematic analysis, we distinguished some themes which explain why they like Victoria and how they read it. We showed that women were being attracted by and simultaneously very cautious of Victoria. In fact, they know that Victoria present them different cods which are not compatible with their own situation. In addition, comparison between ours and theirs provided them with a situation to read the text actively. Accordingly, women distinguished unpleasant native from pleasant foreigner which provided them with an imaginary situation to identify with a desirable and pleasant role.
\end{abstract}

Keywords: Farsi1, Iran, satellite channels, local/global, women's readings

\section{Introduction}

As far as the global cultural consumption is concerned, this is a far more appreciated idea that consumption is, on the one hand, an active practice (Adriaens, 2014; Buckingham, 1987; Dembo, 1972, 1973; Hobson, 1982; Hodge \& Tripp, 1986; Ang, 1982; Walsham, 1999), and a local-contextual action (Arjun Appadurai, 1996; Bhabha, 1994; Jackson, 2004; Kothari \& Laurie, 2005; Hall, 1991b; Tamlinson, 1991) on the other. However, it seems that some important issues are still remained debatable which require more contextual and empirical oriented researches. Although, many researchers, based on some empirical data, have shown that how global cultural products consume in different socio-cultural contexts (Abu-Lughod, 1989; Bielby \& Harrington, 2005; Sinclair \& Cunningham, 1996) only few of this situations are similar to the condition of global cultural products consumption in Iran. In this article, we are not intended to challenge theories like "the active audience" or the term "active cross-cultural consumption", since we think, nowadays, these terms are part of our take for granted premises in media and cultural studies. Nevertheless, we argue that investigation of cross-cultural consumption in the Iranian background provide us with some interesting and different data, which leads us to find out how creative cultural consumption may happen in a different ideological and more or less political situation. Accordingly, we may approach to "somewhat more flexible and complex paradigms", as Straubhaar (1991, p. 43) said, which are required for the current situation of the Local/Global encounter in some peripheral countries like Iran.

First of all, Iranians are formally restricted to access and use most of global/Westernized cultural products. Then, living according to so-called the Westernized life styles is always forcefully prohibited. The supreme leader of Iran, for an example, 33 years after the victory of Islamic Republic, in one of his famous sermon in North Khorasan (2012) introduced the term "Islamic Life Style", which has been rehearsed at least in his 16 subsequent speeches since then. In these orations he emphasized all cultural and governmental organization are responsible to preserve such religious and so-called "pure and safe way of life". Following this command, nowadays, you can see people's real war, instead of symbolic battlefield (see Fisk 1989) with the authorities in the streets and some public places such as malls and city centers. Secondly, not only public places but also private spheres like home and personal activities such as TV viewing are under control and confined to some restrictive rules. A "Big Brother', in Orwell's sense, determines which program and how can be watched. Accordingly, based on a filter-based cultural policy making, there is just one monopolized audio-visual broadcasting organization (IRIB) 
on the one hand, and by using many complicated technologies many international satellite channels are banned and remained out of people's access, on the other.

In this article, based on in-depth interviewing and by examining women's viewing behavior, we argue that reading global visual texts (like one of the most popular family satellite series, Victoria, in Iran) is no zero-sum game, rather local variables reinforced and simultaneously, restrict women's reading. In other word, we demonstrate how people are able to "re-articulate and re-appropriate the messages of global popular cultural form" (Ryoo, 2009, p. 137) to express their local conditions of existence. Likewise, we argue that how this mechanism can be specific based on each local context. Taking these debates further, we try to show new details of the process of activity on the one hand, and illustrate how "hybrid intersections of the local with the global" (Kraidy, 1999, p. 456) happens in the Iranian context of visual cultural consumption.

\section{Satellite Channels and the Emergence of a New Enemy: A Brief History}

Since the early 1990s, Iranians have had access to analogue receivers which could receive only a limited number of satellite channels: Turkish Satellite, European Satellite and Indian Satellite. In 2000, after Hot Bird satellite series have been launched into the air, digital receivers have also entered in the trafficking market of Iran (Alikhah, 2008). In addition, according to a report published by Islamic Republic of Iran Broadcasting (IRIB) (Kavand, 2008) 17666 satellite channels can be received in Iran now, while 2000 channels of them can be received with high quality. It is estimated, for example, that nearly 40 million Iranians, at 50 per cent, are constant viewers of satellite channels (Salimi, 2012). In addition, the majority of these viewers spend more than three hours every day watching TV while following the programs eagerly (Metani et al., 2012; Rezaei, 2011).

NITV was the first Persian satellite channel (Shahabi and Jahangardi, 2008) which broadcasted via Hot bird, but after just one year, due to some financial issues, it has launched its program through Tel Star 12. IranTV, Tapesh, Azadi TV, Pars TV, Channel One, PMC and Your TV were some other new TVs which jointed to Tel Star. These channels can be categorized in two broad classes: political and nonpolitical ones. News, round-table discussions and political interpretations are most common form of programs in the first kind of channels in which the producers focused on some critical political themes such as reformism, secularism, and criticism of the regime of Islamic Republic of Iran. In contrast, second category concerns to entertainment, fun, music, game, interview with celebrities and displaying soap operas. Some of these channels like Farsil, Gem Classic, PMC Family and Zemzemeh, show some amusing and dramatic serials which are dubbed into Persian and are originally produced in Korea, Turkey and Latin America. MBC Persia is another popular channel which presents films and some Turkish and American series with Persian subtitle. In addition, some of these channels are rather concerned to education and produce programs such as cookery, headdress, dance training, immigration affairs and psycho-medical consultancy. Advertising is another main topic of some channels such as ME Shop, Persian TV Market and EZ Shop. Nejat TV, Mohabat TV are religious oriented channels and National Jeographic Farsi shows documentaries and counts as a scientific oriented network. In addition to these two categories, new channels came to exist, which act more professionally than the previous ones and have some more efficient familiarity with their audiences. BBC Persian, for example, is news based channel and may be the most popular one. Yet it broadcasts a variety of entertaining programs such as documentaries. Manotol is another good example which represents this new category. It seems Persian audiences like these channels more than channels like $V O A$ which follows apparently a special political approach.

The story of Iranian encounter with satellite programs has been started after launching Star TV. No sooner had the cultural authorities in Iran started analysing the consequences of new event than it started broadcasting its program. Immediately, in its dispatch from New Delhi, Islamic Republic News Agency (IRNA) reported "the various channels of Star TV, which are being produced and broadcasted cogently, present Western culture to...Iranian audiences gradually" (Mohsenianrad, 1993, p. 20). It seems that IRNA's concern was not illusive and instantaneously satellite dishes conquered most of houses roof in Tehran and some other major cities. Accordingly, since April 1993 satellite dishes and programs have been disputed and fought over as a canonical debate (Arjmandi, 2001) in so far as the supreme leader of Iran labelled satellite as "the new enemy" which has aimed to devastate Islamic integrity especially among the Iranian youth. In addition, like the 'Six Nos' policy in China and other national gate-keeping strategies in some Asian countries (Chadha \& Kavoori, 2000), in 1995, the Iranian Parliament passed a law against trading, installing, repairing and using any type of satellite equipment. In fact, the vast number of satellite channels and their easily accessibility has been a main upsetting point for the religious and centralized cultural policy making system in Iran. Consequently, not only the production and the broadcast of cultural (visual) programs are controlled by the state organizations and institutions, but viewing of different visual programs is also planned to be under control. Accordingly, "the cultural commission of Iranian parliament" in cooperation with NAJA (the police) and IRIB has recently tried to 
gain a new bill in order to prohibit, effectively, the use of satellite receiver (Moj News Agency, 2011). In doing so, NAJA is supposed to guarantee the implementation of law, even forcefully.

Media policy makers and religious authorities are signaling that satellite waves are socio-culturally hazardous (Chadha \& Kavoori, 2000) which threatening Islamic public culture (Alikhah, 2008; Khamenei, 1997, 1998; Khatami, 2012a,b; Laridjani \& Malekitabar, 2008; Laridjani, 1995; Majma Tashkhis Maslate Nezam, 2010; Taghavi, 1995). Similar to the theoretical model of cultural and media imperialism (Boyd-Barrett, 1977; Matterlart, 1979; Schiller, 1976) in which the influences of Western cultural values on none-Western cultural milieu is emphasized apparently, policy makers, and especially, the clergy, argue that watching satellite channels results in declining the foundations of Islamic culture-based family as well as religious beliefs. They believe that these channels are the main cause of transformation and modification of youths' culture and their religious faith. Therefore, they, especially Persian TV networks, which broadcast their waves from overseas, considered as "the great threat" and politically as a disruptive phenomenon, in so far as Ali Khamenei (2003) named all forms of satellite programs as a kind of "cultural invasion" and "cultural NATO", which has been aiming at the building blocks of Islamic Culture in Iran. Cultural officials, apparently, presuppose that the audiences of these channels sit in front of TV and passively watch their programs and are ideologically captured by this visual text. At best, this is an only hypothesis that has not been tested sufficiently among Iranian watchers yet. In addition, As Sreberny (2006, p. 607) argued, nowadays, international media environment is more complex than the world which has been illustrated in some approach such as cultural and media imperialism. Then, we show that the audiences, based on their background of local and environment variables, encounter with the programs and form their own specific reading of its movies and series.

\section{Local/Global Debate}

Nowadays, it is difficult to imagine a plain and one-directional relationship between the global on one hand, and the local on the other. In spite of the global cultural homogenizing power, Homi Bhabha (1994), Stuart Hall and Arjun Appadurai (1996), for instances, argue that the local has it's potentiality to alter the global cultural materials. It seems that, "global post-modernism", as Hall said (1991a), is a heuristic term to characterize the relationship, which is basically negotiative. Nevertheless, one of the most important necessities is to investigate more efficient data to show what exactly the meaning of negotiation in people's lived experience is. As a matter of fact, mostly, the capacity of the local, when it encounters with the global, is attributed to an ambiguous creative and active potentiality which is not usually well-illustrated. Active audience approach, for an instance, has been applied in a variety of socio-media research (Buckingham, 1987; Dembo, 1972, 1973; Hobson, 1982; Hodge \& Tripp, 1986; Ang, 1982; Walsham, 1999). However, the notion of active has been remained problematic yet (Silverstone, 1994).

Broadly speaking, activity is not an individual character per se but a product of a process with several components. Subjects (viewers), texts and socio-cultural variables are the elements of the process of activity. Stuart Hall (1980) in his seminal work, "encoding and decoding the television discourse", argues how television audiences can make an active communication with tele-visual programs (texts). In fact, an individual with different "subject position" in Laclau and Mouffe's sense (2001) and different access to discourses is able to read texts differently. Nevertheless, creative reading comes from the polysemic character of texts as well. Polysemy and multivocality provided readers with different possibilities to read cultural texts (Fiske, 1989). In sum, activity is a disposition which can be realized when an individual consumes a cultural product in his or her local socio-cultural context.

It seems that global cultural texts may find different fates around the world. These texts, as Tamlinson (1991) claimed, has heterogeneous effects in different local cultures. By appealing to "interplay of mediations", he points to the variables, such as social network and social settings that affect the process of decoding in different cultures. This term, as Strelitz (2002) said, concerned to "uneven effect" of global media in local cultures. In other words, this model of media usage insists on localized media consumption which is against those theories that emphasizing on media texts (see for example, Baudrillard, 1983; Kellner, 1995). Baudrillard's analysis of "hypertext" and "the end of the social" (1983) is one of the extremist approaches to study media culture. He argues that people are "narcotized" and "mesmerized" in the media-saturated world in which they cannot distinguish "the real" from the virtual simulated facts: hyper-reality. In fact, in the sense of Baudrillard's theory social categories implode and people in the media saturated-world act as a member of mass society. Drawing on the process of activity metaphor, on the contrary, localized media consumption recognizes socio-cultural categories as critical factors in the process of decoding. In fact, people's "cultural experience", which is the building block of their reading, is grounded in these categories. 
Once again, here, the term "interplay of mediations" that refers to a distinction between cultures ("lived experience") from media as a virtual text is heuristic. Undoubtedly, the distinction between culture and media is more important but it should not be exaggerated. It is an analytic separation, since they are intertwined to each other. In addition, discourse is critical for this coalescence. In other words, instead of media and culture distinction triangular model consist of everyday life, available media and accessible discourses are the very condition for analyzing audiences' behaviors. Therefore, in our view, this model is more efficient than the model suggested by Tamlinson (1991). People read the global cultural products differently because their subjectivities are formed in different discourses. People experience these discourses through their connections to a variety of media which are either global mass or restricted local media. In sum, according to localized media consumption approach media culture is activated by local consumers around the globe. Nevertheless, neither "a new form of global culture" nor a "silent majority" (Boudrillard, 1983) is the dominant pattern of a relationship between media and audiences. Localized media consumption de-centers the role of media text in the process of decoding and focuses on socio-cultural variables.

\section{Methodology}

This research organized to gather qualitative data among women who were living in Tehran. By using purposive-theoretical sampling strategy 30 women were selected, and snowballing technique was the way to access to the cases which was often effective. We didn't have another choice, because of broad restriction to use satellite receiver in Iran there are many problems to do such a kind of researches among women. In addition, we had to find the people who were watching Farsil and especially were the audience of Victoria. Altogether, 30 women from 20-50 years of age from different careers (student, unemployed, housekeeper, secretary, teacher and school principal) and different level of education (high school graduate to postgraduate) were interviewed. The research was conducted with concentration on providing rigor and trustworthiness (Lincoln, 1995) conditions. In doing so, triangulation of researcher and member checking techniques were used in two phases of data gathering and writing up respectively. Interviews lasted for about three months, from early May to late September 2012. Before interviewing we made appointment to meet interviewers through telephone call or face to face and briefly explained about the research, its subject and the goal of interviewing. Moreover, the interviewees were assured that their speeches might be cited only on the condition of anonymity, and their recorded voices would be accessible to no one. Interviews were done in a deep and detailed way, so 120 to 150 minutes were allocated to each one. Through using recorder data recorded, but in some cases the interviewees objected and we made notes at the place. Interviewees' homes were determined as the place of interviews.

\section{Struggle for Viewing}

Between 20:00 to 22:00 Iranian family members come together and spend a little time with each other, while watching TV as their more usual and favorite hobbies. Nevertheless, this is really a surface of an implicit battle on some vital issues in familial and social level. Remote control and changing channels for a favorite program, for instance, is subject of this struggle. Who should rule the remote and which channel? On the ground of a relatively patriarchal structure of Iranian families it seems that the answer is clear: the men (fathers/sons). Interestingly, this is not the whole story. In the case of watching Victoria sometimes, as Farzane (45 years old) says, they impose their choice on other members of family. It seems that nothing can prevent them to fallow their favorite program. Farnaz is one of the good examples of the women who usually win the battle because, as she said, "nobody can ask me for dinner or anything else...while I'm watching Victoria... they can accompany me or deal with their own works." Although Farnaz could manage the time and channel but sometimes women try other alternatives. They may fail but this failure doesn't prevent them to try other ways and options. They, for example, can watch the program tomorrow morning, when the respective section is relayed. In sum, the mere viewing behavior in families might be considered as a symptom of new current challenges in Iranian society, which is centered on the women struggles against the established masculine society.

Nevertheless, there is another problem here which is rooted in Iranian family culture and connected to parents-children relationship. In many families children especially girls are not allowed to watch such a program, then mothers were being faced with many difficulties for following their favorite program. Marzieh (42 years old), for example, thinks Victoria is unique but she used to watch it alone or just with her husband. She doesn't intent to let her children to watch it because, other than some sexual matters, it makes her children surprised in so far as they were asking her some strange questions which she really could not answer them. But this is not just a parental problem, single girls who lives with their parents have similar problem too. Watching Victoria, as Sanaz said (22 years old, single) is not a comfortable hobby for the young and single girls. They should sit in front of TV, while "some scenes are not suitable and actually couldn't be watched together". By the same token, Tahereh ( 25 years old, single), as another example, says that she is somewhat shocked by actress's licentious, 
disapproving moral and too open clothing.

\section{Watching for Entertainment and Calming Down}

One of the main reasons for Iranian audiences to get interested in Victoria is amusement and cheer. From this point of view, Victoria meets their various needs for entertainment that seems can be met hardly in their daily life. Data shows that women have no more chances for spending their leisure time in public spheres and they used to spend it in front of TV programs (Kazemi, 2005). We named this as media oriented pattern for passing leisure time which is dominant among the majority of the Iranian people. Nevertheless, domestic TV is too dreary to attract the audiences (see Sreberny-Mohammadi \& Mohammadi, 1990), even those people who have been counted devout citizens and believe in IRIB as religious machinery (Javadiyeganeh \& Azizi, 2008), and then, they are used to watching satellite programs despite the prohibition of using satellite devices in Iran. Regardless of the prominent and preferred cods in the serial text, Victoria provides them with a cheerful and joyous time, which is so different from their real daily life in the society and from the content of domestic TV program. Maryam (25 years old), for example, confirms that Victoria may be in a bad repute, but it is really fantastic and amusing. She thinks that "it attracts people like me who seek some amusements to get rid of mental tensions and weariness of work and very social stressful life". As a matter of fact, people draw a clear boundary between serious and funny media programs. They argued that the content of domestic TV programs are usually gloomy, joyless and serious, which are perpetually seeking to construct its desirable ideological meanings and concepts. In addition, watching Victoria provides female audiences with a different condition under which they can escape from un-colored programming. This procedure refers to a series of formal rules that determine, for example, decors and characters' clothing, especially actresses, which usually results in apathetic and boring visual texts. Furthermore, domestic series have an un-colored depth too, by which we refer to a more or less homogenous ideological theme, which is prioritized in the texts by constant surveillance of National TV programming procedures. Consequently, people search for some visual programs that help them to have a colored and fun leisure time: "Imagine, after a long heavy and, occasionally boring work you're in home and turn on the TV: wars, social protests, negative news from Europe and the USA and so on are the main images that you can see." (Shahnaz, 28 years old)

Finding similarities and process of identification through comparison is a very common character of Iranian women viewing behavior. Firstly, Victoria confronts the women with a situation in which they can compare their real social condition and visual reality. In fact, they can see how much their situation is similar to the familial positions in the serial which produced and watched globally. By identifying their familial situation with families in Victoria they mitigate tensions and pressures on their shoulders and justify themselves that this is not just their problem. Functioning as a modifier, accordingly, this similarity causes them to feel a bit more convenient. In addition, through this serial the women could find some solutions for their familial issues. Samaneh (24 years old) said that "this serial is full of familial issues...just like the ones we have in our family... betraying, treason and so on". This is not just a comparison rather women try to find some solutions by which they can cope with their own problems in their real life. Secondly, not only similarity, but also a kind of strangeness can be traced in audiences' readings. As a matter of fact, Victoria offers some cods of a different form of life, such as betraying and illegal relationships, which are not more usual in Iran yet. As cited earlier, cultural policy makers and legislators are worrying about penetration and then diffusion of these foreign cultural components into the national Islamic culture. This is actually the trend which is judged and considered as the signs and symptoms of "cultural invasion" by them. Interestingly, audiences' readings revealed that they are able to distinguish these codes and can distinct what is proper or improper according their real life effectively. In addition, by resorting to Victoria they can imagine what may happen in the future and how they can face with some probable issues in their own lives. In so doing, single audiences, find Victoria as a model for resolving possible tensions after marriage, while married women's reading is more linked to their maternal roles. Victoria, here, helps them to be sensitive about their children and then it is more or less sensitizing which motivate them to think of some extremist familial issues. There are some other signs for the impact of Victoria on the audiences' way of life. Clothing and make up is a good example here. Actually, these two cases are the most important challenges against common norms in Iran. Broadly speaking, Hejab has been the center of some critical socio-political changes in contemporary Iran. Two laws i.e. Kashf-e Hejab (the law on unveiling in Pahlavi regime 1935) and Tarh-e Ifaf (the law on veiling in post-revolutionary Iran) confirm this important issue in contemporary Iran. The later, occasionally, is followed by formal or semi-formal maneuvers such as "campaign against unsuitable or mal-veiling [Badhejab/Bihejab]" for controlling clothing in the public spaces. Then, in this situation, clothing and making up are the women's key concerns that affected their readings of Victoria. Basically, they compare domestic TV serials and Victoria and see how Victoria provides them with many attractive and fantastic scenes 
while domestic TV program are truly boring and outdated. Rosa (20 years old) is just one of the women who are really bored of the black and gray background of society on the one hand, and domestic TV programming on the other. She said that "I'm really tired of religious clothing... watching Victoria and her family made me to be in high spirits."

\section{Desire Matters: Ideal Character and Love}

Change is one of the main characteristics of Iranian society which is manifested in altering tastes and desires among different groups, in so far as, the term "generation gap" is a more accepted one (Aghajary, 2003; Firahi, 2003; Ghaderi, 2003; Jalali, 2003; Mansoornejad, 2003; Moeidfar, 2004; Sariolghalam, 2003; Tvakoli, 2003). In fact, the concept is a general term to show changes of Iranians' desires through 34 years after Islamic Revolution, which has revealed itself through different indexes. 'Progressive change in life styles' (Azadarmaki, 2006; Shahabi, 2006; Zokaei, 2006), especially, women's veil and the pattern of relationship between men and women are most salient signs of these changes. In response to these alterations, cultural authorities try to return people's habits and their ways of life to the years of Sacred Defense in which Iran was resisting against an imposed war. In that eight-year war Iranian cultural life trajectories was given and overloaded by ideological values. But, after beginning of the 'reconstruction decade', the time of president Rafsanjani (1989-1997), the socio-cultural conditions have changed dramatically and people have been eager to try new ways and different experiences in their lives. In fact, new process of society construction had been beginning while eight-year war devastation was fading in this decade. In these years, people gradually was trying their chance to access to different cultural resources such as satellite channels and above all, an individualistic spirit substitute for a collective patriotic revolutionary one of the war days. As a matter of fact, a "Long Revolution", in Williams' (1965) sense, started while formal cultural policy makers are steadily insisting on revolutionary character of the society. Although the situation were changing, for example, the years after the imposed war, was actually accompanied by a relative economic affluent condition very soon and signals for renewed international connections emerged, most of people's desires and requests have found no opportunity to fulfill satisfactorily. Since then, in such an atmosphere, TV series like Victoria provide them with an imaginary and virtual space in which they could meet their needs. In addition, by these series they could have reflection on some taboos because these channels opened new windows through which Iranians could see something different from limited cultural life styles. Mahdieh (22 years old), for example, thought that "it is very good that a girl can talk with her family about being abused, sexual problems and altogether every other problem she had... Not only it doesn't teach bad things but also it teaches us that with every kind of life we have, at least be truthful and logical and respect our feelings".

More importantly, Victoria provided Iranian women with an ideal role which they can rarely find in domestic series. Women prefer to watch Victoria because her role shows them a desirable and authoritative character which is not only attractive but also can encounter with familial issues rationally. As a matter of fact, women compare Victoria with domestic channels and seek in satellite programs to find some real character of women which are absent in domestic series. Many different researches indicated that women are shown in inferior positions in visual contexts (Ezazi, 2001; Haj Mohamad Yari, 2003; Islamic Republic of Iran Broadcasting, 1992, 1997, 1999, 1995, 2003a, 2003b, 2004, 2005; Jahandideh, 2003; Karimi, 2004; Pirhayati, 1994; Ravadrad et al., 2008; Ravadrad, 2001; Research Group of Cultural Studies, 2005; Rezaei and Afshar, 2010; Rezaei and Kazemi, 2008). According these researches domestic series represent an unfair and degrading depiction of women in national TV serials. On the contrary, Victoria, as Shokoofeh (27 years old) said, shows a character which displays a real development from a passive woman to an authoritative one. This is actually a desired character which is exciting and inspiring for many audiences of Victoria in Iran. Interestingly, the women found Victoria as an inspiring character and identified themselves with her. Here, a process of identification is ongoing. Part of this procedure is originates from a kind of proximity. To be precise, the visual events within the serial seem to the Iranian audiences so real and concrete, and then they find it very similar to their own condition. Lida (30 years old) for instance said that "in spite of some cultural differences, I found it very similar to our current society". For another example, Shahnaz (28 years old) pointed to the proximity too and believed that "It is interesting for me because it teaches me how to treat my children, my husband, friends, acquaintances and relatives."

Like most of soap operas, love is one of the main themes of Victoria. But love affair in this serial generates a different sense among the Iranian audiences in some ways. An extraordinary relationship between an older woman (Victoria) with a younger boy and making a relationship beyond norms are two characteristic of love affair in this serial. Without having an opposite or a fond position, Iranian woman find these relationship attractive and desirable. On the one hand, the romantic world of Victoria helps them to distance themselves though for a short time from socio-cultural restrictions which are made by traditional society and reinforced by religious and political regime. In this imaginary world, they find their desires and feeling fulfilled. On the other 
hand, it seems that they see in Victoria's relationship with her younger lover a kind of womanish resistance and a delightful and mild invasion to the forbidden frameworks of society. Obviously, the audiences show an enthusiasm for a new or different way of life, in which they can distance themselves from the entirely safe life. This would be interesting and surprising if one considers that the Islamic or pure life is the central theme in cultural policy making in Iran. Interestingly, they characterize this visual product as a "desirable excitement", "constructive excitement", "source of hope", "feeling of joy", "unique", "splendid feeling", "delightful", "fantastic" and "pleasing". Explains Farzaneh (45 years old) "I'm found of the love between Victoria's son and Kamila; I like the love between people of very different ages especially the older woman with the younger mom. This kind of love has become more attractive for me than the love between girls and boys of the same age".

\section{Conclusion}

In this article we tied to examine the idea that satellite channels viewing is an important case by which the global-local debate can be studied in a very specific field like Iran. In doing so, we arranged some interviews with women who selected purposively according to their socio-cultural background. We discussed that the mere idea of active consumption is a generally accepted one, and then in such a research we need to go beyond the idea and examine different aspects of these active kinds of cultural consumption. Hence, we tried, in the case of Iranian women viewing behavior, to clarify how the process of activity works. As a matter of fact, we argued that the special condition of the Iranian women's facing with global cultural products results in different reading of these products.

The act of watching Victoria is the sign of some characteristics of social background of reading of satellite programs in Iran, which indicates that this action happens in a context of familial disputes and is a problematic action. As we showed, many of parents prefer to view the programs without their children and they judged Victoria as a cultural text which consists of some destructive elements based on Iranian socio-cultural conditions. But, these women were still the audiences of the serial. In fact, women were being attracted by and simultaneously very cautious of Victoria. In such a situation of enthusiasm and precaution, different and particular reading of Iranian women is formed. In other word, Victoria is not considered as a model of behavior for the Iranian women, but they were conscious about its significations in so far as it could provoke some new imaginations for different ways of life.

Comparison between ours and theirs provided the audiences with a situation to read the text actively. As we showed, the viewer's always compare Victoria with domestic series and TV programs which are indifferent to their real life. We named this kind of indifference as national programming shortage to produce comprehensive and what we called variegated programming for different social groups. On the contrary, women argued that internal TV programs are unilateral and so ideological which are outdated and boring. Accordingly, women distinguish unpleasant native from pleasant foreigner which provided them with an imaginary situation to identify with a desirable and pleasant role. Broadly speaking, Victoria helps them to create a virtual world in which a lot of their desires can be satisfied. Victoria presents them a comfort, cheer, entertainment, colored feeling and some beautiful models of clothing and makeup, which cannot be found in domestic programs. In addition, through Victoria women become familiar with a new situation in which not only they can figure out their probable problems and the solutions but also, they can think on their positions in their society. In fact, through the mirror of Victoria they see how a woman can change her bad situation to a proper, more just and emancipatory one. In sum, in line with active audience literature in developing countries (see Zhou and Russell, 2004) Iranian women, based on their socio-cultural, ideological and political conditions, consume global appealing products in their different ways.

These findings are enough satisfying that the process of activity performs its role and provided people in different area of the world to read the global differently. But, this process can only act in the side of viewers; we think there is another important side that needs to be considered more. By this side we are trying to reanimate the controversy which focuses on the whole "circuit of culture" (Hall, 1997), including production, not only the moment of consumption. As far as the moment of production is concerned, it seems that people who live in peripheral countries/cultures don't have effective access to appealing domestic productions. Accordingly, in spite of Straubhaar (1991) and specially Chadha and Kavoori (2000, p. 243), Iranian audiences showed a different behavior and find global media products more attractive than domestic ones. These findings challenge the assumption that local viewers are more likely to view domestic programs (Straubhaar, 1991) and then concluded a kind of two-way relationships between the local and the global (Li Chang, 2001). As far as news broadcast is concerned, Li Chang was right that some Asian governments put difficulties in the way of expanded proliferation of the Western news waves, but in the case of Iranian viewers, in spite of Islamic government's attempts, we showed that how people prefer satellite channels to domestic ones. 


\section{Declaration of conflicting interests}

The authors declared no potential conflicts of interest with respect to the research, authorship and/or publication of this article.

\section{References}

Abu-Lughod, L. (1989). Bedouins, cassettes and technologies of public culture. Middle East Report, 159(4), $7-12$.

Adriaens, F. (2014). Diaspora girls doing identities: Creating ideal television programmes and narratives of the self. European Journal of Cultural Studies, 17(2), 101-117. http://dx.doi.org/10.1177/1367549413508096

Alikhah, F. (2008). The politics of satellite television in Iran. In M. Semati (Ed.), Media, culture and society in Iran: Living with globalization and the Islamic state (pp. 94-110). London and New York: Routledge.

Ang, I. (1991). Watching television. London: Rutledge.

Arjmandi, G. R. (2001). Satellite live broadcasting: consequences and policies. Iranian Journal of Sociology, 2(6), 83-99 (In Persian)

Azad Armaki, T. (2007). Life style models in Iran. In E. Hajiani (Ed.), Iranians' life style patterns (pp.15-35). Tehran: Center for Strategic Researches of Majma Tahkhis Mslahat-Nezam.

Baudrillard, J. (1983). In the shadow of the silent majorities...or the end of the social and other essays. New York: Semiotext(e).

Bielby D. D., \& Lee. H. C. (2005). Opening America?: the telenovela-ization of U.S. soap operas. Television New Media, 6(4), 383-399. http://dx.doi.org/10.1177/1527476405279861

Boyd-Barrett, O. (1977). Media imperialism: towards an international framework for the analysis of media systems. In J. Curran, M. Gurevitch, \& J. Woollacott (Ed.), Mass Communication and Society (pp. 116-135). London: Edward Arnold.

Chadha, K., \& Kavoori, A. (2000). Media imperialism revisited: some findings from the Asian case. Media Culture Society, 22(4), 415-432. http://dx.doi.org/10.1177/016344300022004003

Dembo, R. (1973). Gratifications found in media by British teenager boys. Journalism Quarterly, 50(3), 517-526. http://dx.doi.org/10.1177/107769907305000315

Dembo, R. (1997). Lifestyle and media use among English working-class youths. Gazette: The International Journal for Communication Studies, 18(1), 24-36.

Ezazi, S. (2001). Structural analysis of sexuality. Tehran: Shahid Beheshti University Press.

Featherstone, M. (1987). Lifestyle and consumer culture. Theory, Culture and Society, 4(1), 55-70. http://dx.doi.org/10.1177/026327687004001003

Fisk, J. (1989). Understanding popular culture. London: Routledge.

Hall, S. (1980). Encoding/decoding. In S. Hall (Ed.), Culture, media, language (pp. 117-128), London: Hutchinson.

Hall, S. (1991a). The local and the global: globalization and ethnicity. In A. King (Ed.) Culture, globalization and world-system: contemporary conditions for the representation of identity (pp. 19-40). London: Macmillan.

Hall, S. (1991b). Old and new identities, old and new Ethnicity. In A. King (Ed.) Culture, globalization and world-system: contemporary conditions for the representation of identity (pp. 41-68). London: Macmillan.

Hall, S. (1997). Representations and signifying practices. London: Sage Publications.

Hartley, J. (1987). Invisible fictions: television audiences, paedocracy, pleasure. Textual Practice, 1(2), $121-138$. http://dx.doi.org/10.1080/09502368708582010

Hepp, A. (2010). Researching 'mediatised worlds': non-mediacentric media and communication research as a challenge. In N. Carpentier, I. Tomanić Trivundža, P. Pruulmann-Vengerfeldt, et al. (Eds.), Media and communication studies: intersections and interventions (pp. 37-48). Tartu: University of Tartu Press.

Hobson, D. (1982). Crossroads: the drama of a soap opera. London: Methane.

Hodge, R., \& Tripp, D. (1986). Children and television: a semiotic approach. Cambridge: Polity Press.

Hoseini, S. E. (2001). Satellite programs, the state sovereignty and the free information principals. Maarefat, 
79(36), 52-68 (In Persian).

Islamic Parliament Research Center. (1995, August). The law for prohibition of satellite facilities. Report, Retrieved August, 20, 2013, from http://rc.majlis.ir/fa/law/show/92510

Islamic Republic of Iran Broadcasting. (1992). Women's depiction in the 'House light' (Cheragh-e Khane) serial. Report, Tehran: The Program Measurement and Studies Center.

Islamic Republic of Iran Broadcasting. (1995). Television's role in women's social character formation. Report, Tehran: The Program Measurement and Studies Center.

Islamic Republic of Iran Broadcasting. (1997). An analysis of men and women's depiction in familial programs: the case of channel one. Report, The Program Measurement and Studies Center.

Islamic Republic of Iran Broadcasting. (1999). Women's depiction in television: a public opinion poll. Report, Tehran, The Program Measurement and Studies Center.

Islamic Republic of Iran Broadcasting. (2003a). A study of love in Iranian serials (Parent's Troubles, The Youth, and the Tenth Night). Report, Tehran: The Program Measurement and Studies Center.

Islamic Republic of Iran Broadcasting. (2003b). Retrieving information of women and media. Report, Tehran: The Program Measurement and Studies Center.

Islamic Republic of Iran Broadcasting. (2004). Women's depiction in domestic series. Report, Tehran: The Program Measurement and Studies Center.

Islamic Republic of Iran Broadcasting. (2005). Comparison between men's and women's social, political, economic and cultural role in domestic serials. Report, Tehran: The Program Measurement and Studies Center.

Jackson, P. (2004). Local consumption cultures in a globalizing world. Trans. Inst. Br. Geogr., 29(2), 165-178. http://dx.doi.org/10.1111/j.0020-2754.2004.00123.x

Javadiyeganeh, M. R., \& Azizi. J. (2008). A survey study of audience satisfaction with the religious programs of radio-television in Tehran. Journal of Media and Religion, 7(1-2), 70-83. (In Persian).

Karimi, S. (2004). A sociological study on sexuality clichés and family structure in domestic serials. Unpublished master dissertation, University of Tehran, Tehran.

Kavand, R. (2008). A qualitative study on satellite Persian channels reception. Unpublished master dissertation, University of Tehran, Tehran.

Kellner, D. (1995). Media culture: cultural studies, identity and politics between the modern and the postmodern. London: Routledge.

Khameneh-ei, A. (2003). Hadise-e Velayat [The Supreme Leader's Sermons]. Tehran: Islamic Development Organization.

Khatami, A. (2012a). Satellite: inviting enemy in home. Keyhan, 18 June, 19952.

Khatami, A. (2012b, October). Satellite scientific programs are erotic too! Retrieved October, 4, 2013, from www.aftabnews.ir/vdcbw9b8srhb59p.uiur.Html

Kothari, U., \& Laurie, N. (2005). Different bodies, same clothes: an agenda for local consumption and global identities. Area, 37(2), 223-227. http://dx.doi.org/10.1111/j.1475-4762.2005.00624.x

Kraidy, M. (1999). The global, the local, and the hybrid: a native ethnography of glocalization. Critical Studies in Mass Communication, 16(4), 456-476. http://dx.doi.org/10.1080/15295039909367111

Laclau, E., \& Moffe, C. (2001). Hegemony and socialist strategy: towards a radical democratic politics. London: Verso.

Laridjani, A., \& Malekitabar, M. (2008). A study on strategic influences of satellite on youth's beliefs. $A$ Quarterly on Strategic Defense Studies [Faslnameh Motaleat Defaei Strategic], 8(27), 135-160. (In Persian)

Laridjani, M. J. (1995). Satellite and Islamic regime. Majles and Pazuoohesh, 2(12), 8-14. (In Persian)

Lin, C. (1996). Looking back: the contribution of Blumler and Katz's uses of mass communication to communication research. Journal of Broadcasting \& Electronic Media, 40(4), 574-581. http://dx.doi.org/10.1080/08838159609364379 
Lincoln, Y. S. (1995). Emerging criteria for quality in qualitative research and interpretive research. Qualitative Inquiry, 1(3), 275-289. http://dx.doi.org/10.1177/107780049500100301

Livingstone, S. (2009). On the mediation of everything. Journal of Communication, 59(1), 1-18. http://dx.doi.org/10.1111/j.1460-2466.2008.01401.x

Majma Tashkhis Maslate Nezam. (2010). Investigating apparent and obscure goals of Farsi one channel. Tehran: Center for Strategic Research.

Mattelart, A. (1979). Multinational corporations and the control of culture. Harvester Press and New Jersey: Humanities Press.

Metani, M., Hasanzadeh, R., \& Farhangi, A. (2013). Ghaemsharians' attitudes toward satellite channels. A Quarterly Journal of Iranian Association of Cultural Studies and Communication, 14(53), 129-156. (In Persian).

Moeidfar, S. (2004). Generation gap or cultural rupture: investigating generation gap in Iran. Nameh Olom Ejtemai, 24(3), 55-80. (In Persian).

Mohsenianrad, M. (1993). Satellite dishes in Asia and the states' reactions. Majles and Pazuoohesh, 2(11), 15-44. (In Persian).

Moj News Agency. (2011). Prohibition doesn't decrease people enthusiasm for satellite. Retrieved October 23, 2014, from http://www.mojnews.com/fa/Miscellaneous/ViewContents.aspx?Contract=cms_Contents_I_ News\&r=779370

Moores, S., \& Metykova, M. (2010). I didn't realize how attached I am: on the environmental experiences of trans-european migrants. European Journal of Cultural Studies, 13(2), 171-189. http://dx.doi.org/10.1177/1367549409352278

Moores, S. (2006). Media uses and everyday environmental experiences: a positive critique of phenomenological geography.Particip@tions, 3(2). Retrieved May 5, 2014, from www.participations.org/

Ravadrad, A. (2001). Transformations of woman's role in society and television. JWICA (A Quarterly Journal of Women Research, 1(1), 133-157. (In Persian)

Ravadrad, A., Montazerghaem, M., \& Sarkarati, M. (2008). Women's interpretation of female's identity representation in television. Iranian Journal of Cultural Research, 1(2), 1-22. (In Persian).

Raymond, W. (1965). The long revolution. London: Penguin.

Research Group of Cultural Studies. (2005). A content analysis of post-revolutionary cinema: the case of women and their deserved position in Islamic system. Report, Jahad Daneshgahi, Tehran.

Rezaei, M., \& Afshar, S. (2010). Iranian tv series and women's representation: the 'Long Death of One Dream' \& 'Maternal Song'. JWICA (A Quarterly Journal of Women Research), 1(4), 75-94. (In Persian).

Rezaei, M. (2011). Cultural consumption and identity formation among university students in Tehran. Report, Institute for Social and Cultural Studies, Tehran.

Rezaei, M. A., \& Kazemi, R. (2008). Gender policy in tv: a qualitative analysis of three Iranian tv series. JWICA(A Quarterly Journal of Women Research), 6(3), 85-112. (In Persian).

Ryoo, W. (2009). Globalization, or the logic of cultural hybridization: the case of the Korean wave. Asian Journal of Communication, 19(2), 137-151. http://dx.doi.org/10.1080/01292980902826427

Salimi, O. (2012, September). Half of Iranians watch satellite channels! Retrieved September, 20, 2013, from http://www.khabaronline.ir/detail/184508/

Schiller, H. (1976). Communication and cultural domination. White Plains: International Arts and Science Press.

Shahabi, M., \& Jahangardi, M. (2008). The social origins of association: patterns of Tehrani audiences with the Persian speaking satellite channels. Iranian Journal of Cultural Research, 1(2), 23-55. (In Persian).

Silverstone, R. (1994). Television and everyday life. Oxford: Rutledge.

Sinclair, J., Jacka, E., \& Cunningham, S. (1996). New Patterns in Global Television: Peripheral Vision. Oxford: Oxford University Press.

Sreberny, A. (2006). The global and the local in international communications. In M. G. Durham, \& D. M. Kellner (Eds.), Media and cultural studies: keyworks in cultural studies (pp. 604-625). Oxford: Blackwell Publishing. 
Sreberny-Mohammadi, A., \& Mohammadi, A. (1990). Hegemony and resistance: media politics in the Islamic Republic of Iran. Quarterly Review of Film and Video, 12(4), 33-59. http://dx.doi.org/10.1080/105092 09109361362

Straubhaar, J. D. (1991). Beyond media imperialism: asymmetrical interdependence and cultural proximity. Critical Studies in Mass Communication, 8(1), 39-59.

Strelitz, L. N. (2002). Media consumption and identity formation: the case of the 'Homeland' Viewers. Media, Culture \& Society, 24(4), 459-480. http://dx.doi.org/10.1177/016344370202400401

Taghavi, S. R. (1995). Prohibition of Satellite Receivers and Further Steps. Majles and Pazuoohesh, 2(11), 49-72. (In Persian).

The Supreme Leader's Sermon in North Khorasan. (2012, February). Retrieved February 25, 2013, from http://www.leader.ir/langs/fa/index.php?p=contentShow\&id=9985

The Supreme Leader's Sermon. (1997, February). Retrieved February 25, 2013, from http://www.leader.ir/langs/fa/index.hp?p=bayanat\&id=1278

The Supreme Leader's Sermon. (1998, February). Retrieved February 25, 2013, from http://www.leader.ir/langs/fa/index. php?p=bayanat\&id

Tomlinson, J. (1991). Cultural imperialism. London: Pinter Publishers.

Zhou, N., \& Russell, W. B. (2004). Chinese consumer readings of global and local advertising appeals. Journal of Advertising, 33(3), 63-76. http://dx.doi.org/10.1080/00913367.2004.10639169

Zokaei, M. S. (2007). Transforming life style. In E. Hajiani (Ed.), Iranians' life style patterns (pp. 73-101). Tehran: Center for Strategic Researches of MajmaTahkhis Mslahat-Nezam.

\section{Copyrights}

Copyright for this article is retained by the author(s), with first publication rights granted to the journal.

This is an open-access article distributed under the terms and conditions of the Creative Commons Attribution license (http://creativecommons.org/licenses/by/3.0/) 